\title{
Does It Help to Call a Spade a Spade? Examining the Legal Bases and Effects of Rule of Law-Related Infringement Procedures Against Hungary
}

\author{
Lisa H. Anders and Sonja Priebus
}

\section{INTRODUCTION}

In view of the "rule of law crisis" (Reding 2013), politicians and scholars started discussing the EU's tools to defend the rule of law and democracy in its member states. This chapter focuses on one of these tools, the infringement procedure.

Scholars agree that infringement procedures are generally an effective instrument to induce compliance with EU Treaty obligations and secondary law (Börzel 2003). Whether they are also a suitable means to

\section{H. Anders $(\bowtie)$}

Institute of Political Science, Leipzig University, Leipzig, Germany e-mail: 1.anders@uni-leipzig.de

S. Priebus

Institute of Political Science, Otto-von-Guericke-University Magdeburg, Magdeburg, Germany e-mail: sonja.priebus@ovgu.de

(C) The Author(s) 2021

A. Lorenz and L. H. Anders (eds.), Illiberal Trends and Anti-EU Politics in East Central Europe, Palgrave Studies in European Union Politics, https://doi.org/10.1007/978-3-030-54674-8_10 
enforce the EU's foundational values and to combat rule of law backsliding in EU member states is, however, still contested. Some regard the instrument as "too narrow to address the structural problems" of backsliding (Scheppele 2016, p. 109), fearing that it forces the Commission to misconstrue rule of law problems as instances of non-compliance with EU secondary law (Pech and Kochenov 2019, p. 5). This would allow the targeted governments to downplay the severity of the problems at hand, react with minimal legal changes to satisfy the Commission's requirements and then proceed with their illiberal agenda. Some suggest that rule of law-related infringement procedures induce symbolic compliance at best (Batory 2016) and might even be counterproductive if the targeted governments succeed in framing the Commission's criticism as an illegitimate interference into domestic politics (Schlipphak and Treib 2016). Others, in contrast, are more sanguine, deeming infringement procedures a "powerful alternative" to the procedure under Article 7 of the Treaty on European Union (TEU) and expecting them to contribute to depoliticising conflicts concerning the rule of law (Schmidt and Bogdanowicz 2018, p. 1062). The Commission has also recently shown a renewed interest in the instrument, announcing that it would continue to use it in rule of law related cases (European Commission 2019b).

Our empirical knowledge about the deployment and actual effects of infringement proceedings in rule of law related cases is, however, still limited. So far, scholars have focused predominantly on the most prominent cases, while systematic studies are lacking. Thus, we do not know on what legal basis the Commission introduces these proceedings, whether it always refers to concrete breaches of EU secondary law as assumed in literature or whether it also cites more fundamental values. Furthermore, we lack knowledge about the targeted government's legal and public reactions. To contribute to closing this gap, we empirically examine all infringement procedures with rule of law significance launched against Hungary since 2010. Hungary is an ideal case to study since it has already faced seven rule of law-related infringement procedures. This relatively high number of cases enables us to examine the legal bases and effects of these proceedings and explore patterns over time.

The chapter is structured as follows. The next section briefly takes stock of research on infringement procedures and discusses the arguments for and against the deployment of this tool in rule of law related 
cases. Section 3 examines the legal bases of the infringement procedures with rule of law relevance launched against Hungary since 2010, while Section 4 briefly sketches the Hungarian government's reactions. Section 5 is devoted to exploring the interplay between Brussels and Budapest over time. The concluding section summarises and discusses the main findings.

\section{Infringement Procedures as an Instrument Against Rule of LAW BACKSLIDING IN EU MEMbER STATES?}

The meaning of the rule of law is notoriously contested (see Chapter 9). A thin concept simply equates the rule of law with the rule by law. More common are thicker concepts relating the rule of law to checks and balances, the independence of the judiciary as well as the guarantee of basic human rights (Merkel 2012). It is exactly these principles that are being systematically attacked in Hungary. Since Fidesz and its coalition partner KDNP won a two-thirds majority in parliament in 2010, the country's constitutional order has been changed dramatically. The government has centralised power within the executive, turned the National Assembly into a rubber-stamp parliament and considerably weakened the Constitutional Court. Besides, it adopted an electoral law designed to favour Fidesz and passed several laws to strengthen the government's influence over the media and to curb the activities of civil society organisations (Ágh 2018; Priebus 2016). As a result, the former democratisation frontrunner is considered a prime example of rule of law backsliding ${ }^{1}$ or even autocratisation (see Chapter 12). Against this backdrop, and in view of similar developments in other member states, a growing body of research discusses the EU's political and legal tools to tackle backsliding in its member states.

Compared to other tools, such as the "nuclear option" of Article 7 TEU, the infringement procedure has several advantages. Most notably, its decisional thresholds are much lower and the defiant member states

\footnotetext{
${ }^{1}$ Rule of law backsliding is defined as the process "through which elected public authorities deliberately implement governmental blueprints which aim to systematically weaken, annihilate or capture internal checks on power with the view of dismantling the liberal democratic state and entrenching the long-term rule of the dominant party" (Pech and Scheppele 2017, p. 10).
} 
enjoy "a full set of procedural guarantees and rights" (Schmidt and Bogdanowicz 2018, p. 1065). The procedure starts with informal consultations between the Commission and the state suspected of violating EU rules. Then, the Commission can send a "letter of formal notice" to the member state concerned. If dissatisfied with the reaction to the letter, it can give a "reasoned opinion", and, if non-compliance prevails, bring the case before the Court of Justice of the European Union (CJEU). Relying on informal consultations and persuasion, the Commission usually tries to tackle non-compliance in the early stages of the procedure and avoids open conflicts with non-complying member states (Closa 2019). In fact, the vast amount of cases are settled in the early stages of the procedure (Börzel 2003, p. 207), showing that the Commission's enforcement actions are generally quite effective in inducing compliance with EU law (Panke 2010).

Infringement procedures can be initiated by the Commission if it "considers that a member state has failed to fulfil an obligation under the Treaties" (Article 258 TFEU). The Commission must base its proceeding on clear legal EU norms. The EU's foundational values of democracy and the rule of law, however, are legally undetermined as Article 2 TEU mentions but does not further specify these terms (Magen 2016, p. 1051; Müller 2015, p. 147). This does not mean that the EU's foundational values are explicitly excluded from the supervisory remit of the Commission (Hillion 2016). Yet, as these values do not provide a clear legal basis for their enforcement, the Commission has to look for a "more technical but more clearly established legal basis to prosecute the action" (Blauberger and Kelemen 2016, p. 325).

Whether the resulting indirect and piecemeal approach can restrain backsliding is questionable. As also stressed by the Commission, it is only a viable route when the concerns of the rule of law at hand "constitute, at the same time, a breach of a specific provision of EU law" (European Commission 2014, p. 5). Besides, critics underline that it misconstrues or miscategorises the problems at hand. Broader backsliding tendencies are not named as such but are reframed by the Commission as concrete breaches of EU law in individual proceedings (Scheppele 2016). This enables backsliding governments to respond "satisfactorily to the outstanding complaints without having to change anything essential about its illiberal reforms" (Jenne and Mudde 2012, p. 150). Others even posit that the targeted governments merely engage in symbolic 
compliance and simply create the appearance of norm-conform behaviour (Batory 2016).

Besides, scholars debate how rule of law-related infringement procedures can be rhetorically exploited. Some contend that if the Commission sues backsliding states on more technical grounds and reframes rule of law problems as breaches of secondary law, it allows backsliding governments to downplay the actual conflicts by publicly presenting rule of law related problems as ordinary compliance difficulties (Jenne and Mudde 2012). Some scholars, therefore, suggest that the Commission should engage in systemic infringement actions and bundle "a group of specific violations together" (Scheppele 2016, p. 107) to highlight the systemic and persistent character of rule of law backsliding. Then, cases would not be miscategorised, providing the Commission with "greater options and a clearer message of response to rule of law backsliding" (Pech and Kochenov 2019, p. 5). Others, moreover, warn that rule of law-related infringement procedures might invite the errant governments to play a "blame game" (Schlipphak and Treib 2016). Governments could frame any EU intervention as a politically motivated, illegitimate interference "in policies beyond the remit established by the EU Treaties" (Dawson and Muir 2012, p. 473) and themselves as defenders of their nation, which, as a consequence, could alienate citizens from the EU. Whether governments really succeed with these strategies is doubted by others. Highlighting the high levels of public trust in the Commission and the CJEU, they suggest that infringement procedures might be welcomed by citizens and help to depoliticise current conflicts over the rule of law (Blauberger and Kelemen 2016; Schmidt and Bogdanowicz 2018).

In short, the concrete effects of infringement procedures as instruments against democratic backsliding remain unclear. Up until now, scholars have mainly focused on the most prominent infringement procedure (which addressed the lowering of the retirement age of judges) and generally concluded that infringement procedures are ineffective in remedying rule of law problems (Müller 2015; Scheppele 2016). Systematic empirical studies on the deployment and the legal effects of infringement procedures in all cases with rule of law relevance as well as on the government's communication in these cases are still lacking (see Szente 2017 for an exception). This chapter contributes to fill this gap by analysing all rule of law-related infringement procedures launched against Hungary since 2010 (see Table 1). So far, studies on Hungary have identified six 
Table 1 Rule of law-related infringement procedures against Hungary. Source authors' compilation

\begin{tabular}{|c|c|c|}
\hline No. & Beginning $I P^{a}$ & Subject triggering IP \\
\hline 1 & $12 / 2010^{\mathrm{b}}$ & $\begin{array}{l}\text { Title: Media legislation } \\
\text { Trigger: Act CIV of } 2010 \text { on the Freedom of the Press and } \\
\text { the Fundamental Rules on Media Content }+ \text { Act CLXXXV of } \\
2010 \text { on Media Services and Mass Media }\end{array}$ \\
\hline 2 & $01 / 2012$ & $\begin{array}{l}\text { Title: Independence of Central Bank } \\
\text { Trigger: Fundamental Law of Hungary }+ \text { Act CCVIII of } \\
2011 \text { on the Hungarian National Bank }\end{array}$ \\
\hline 3 & $01 / 2012$ & $\begin{array}{l}\text { Title: Independence of Judiciary: Retirement age of judges, } \\
\text { prosecutors and public notaries } \\
\text { Trigger: Fundamental Law of Hungary }\end{array}$ \\
\hline 4 & $01 / 2012$ & $\begin{array}{l}\text { Title: Violation of Independence of Data Protection } \\
\text { Supervisory Authority } \\
\text { Trigger: Fundamental Law of Hungary }\end{array}$ \\
\hline 5 & $04 / 2017$ & $\begin{array}{l}\text { Title: Violation of EU law by amendments to the Hungarian } \\
\text { Higher Education Law } \\
\text { Trigger: Act XXV of } 2017 \text { ("Lex CEU") }\end{array}$ \\
\hline 6 & $07 / 2017$ & $\begin{array}{l}\text { Title: Violation of EU law by the Act on the Transparency of } \\
\text { Organisations Supported from Abroad } \\
\text { Trigger: Act LXXVI of } 2017 \text { ("NGO-law") }\end{array}$ \\
\hline 7 & $07 / 2018$ & $\begin{array}{l}\text { Title: Violation of EU law by means of the Act VI of } 2018 \\
\text { amending certain acts with respect to measures against illegal } \\
\text { immigration and the } 7 \text { th amendment to the Fundamental Law } \\
\text { of Hungary } \\
\text { Trigger: } 7 \text { th Amendment to Fundamental Law of Hungary } \\
\text { "Stop-Soros") } \\
\text { Act No VI of } 2018\end{array}$ \\
\hline
\end{tabular}

a Date of letter of formal notice

${ }^{b}$ This case was closed before a letter of formal notice was issued. We take the letter written by then-commissioner Neelie Kroes to the Hungarian government as the starting date

such cases; we additionally consider another recent case, the infringement procedure launched against the so-called "Stop Soros" legislation.

Drawing on Commission press releases and public statements of Commissioners, we first examine the legal basis referred to by the Commission when starting infringement action in rule of law related cases. In particular, we analyse whether the Commission bases its infringement actions solely on "technical" Treaty obligations and secondary law or if it also refers to the rule of law or other fundamental values connected to it. Besides, using a database of Hungarian legislation (https://net. jogtar.hu) as well as the Official Gazette of Hungary (Magyar Közlöny), 
we analyse Hungary's legal reactions to these infringement procedures. Furthermore, we take a closer look at the government's public reactions, relying on official press releases, summaries of government members' public appearances and full transcripts or summaries of interviews with government members issued within two weeks after each Commission's announcement of action against Hungary and published on the government's official website.

\section{Miscategorising the Problems? The Legal Bases of Rule of LaW-Related Infringement Action}

In all cases under examination, the Commission did not refer directly to Article 2 TEU, the EU's foundational values of democracy or the rule of law, but based its infringement actions on other EU law violations (see Table 2 in the Appendix for an overview). In most cases, however, it complemented technical references to breaches of Treaty provisions and secondary law with references to the Charter of Fundamental Rights of the European Union (CFR).

In this vein, the Commission framed the media legislation package of 2010 (case 1) primarily as an incorrect transposition of the EU's Audiovisual Media Services directive, but also stressed that "fundamental media freedoms such as freedom of expression and media pluralism" as enshrined in Article 11 of the CFR were endangered (European Commission 2011; Kroes 2011). This was in line with general criticism voiced by observers that the media legislation threatened the freedom of the press by establishing a politically biased Media Council, altering appointment procedures to ensure political influence on the public broadcasting service and demanding "balanced coverage" (Polyák 2015; Várnagy 2011).

Similarly, in the infringement procedure triggered by the restructuring of the Hungarian ombudsmen system (case 4), the Commission referred to both violations of secondary law and CFR provisions. Noting that the former data protection ombudsman's functions had been transferred to a new agency without the former guarantees of independence (Bánkuti et al. 2012, p. 266) and that the incumbent ombudsman for data protection had been prematurely removed from its office, the Commission argued that these provisions violated Article 16 of TFEU as well as Directive $95 / 46 / \mathrm{EC}$ codifying the EU rules on data protection. Additionally, it referred to Article 8 of the CFR guaranteeing the independence of data protection supervisors (European Commission 2012a). 
In the case of the Lex CEU (case 5), which changed the rules for non-Hungarian universities and obviously targeted the private Central European University (CEU) founded by George Soros, the Commission primarily referred to violations of internal market principles. It argued that the law was incompatible with the freedom to provide services and the freedom of establishment as enshrined in Articles 56 and 49 TFEU, respectively, as well as in Directive 2006/123/EC on services in the internal market. At the same time, it also stressed violations of Articles 13, 14 and 16 of the CFR, namely academic freedom, the right to education and the freedom to conduct a business (European Commission 2017b).

Also in case 6, the infringement procedure launched in reaction to the "NGO law" (Act LXXVI of 2017 on the Transparency of the Organisations Supported from Abroad), the Commission communicated that it saw several fundamental principles of the CFR violated. The new legislation obliges NGOs receiving over 7.2 million HUF (about 24,000 Euros) per year from abroad to be registered by a court and to be officially labelled as "organisations supported from abroad" in any publications and on their websites. As for the Commission, this does not only constitute a violation of the free movement of capital, but also of the freedom of association as well as the rights to protection of private life and personal data (European Commission 2017c).

Reacting to the "Stop Soros" legislation (case 7), which further intensified pressure on civil society organisations by specifying that organisations or people who "support or promote illegal immigration" (Act VI of 2018, $\$ 11)$ can be sanctioned with up to one year of imprisonment or even expulsion from the country, the Commission identified a violation of the Asylum Procedure Directive and the Reception Conditions Directive, a breach of Articles 20 and 21 (1) TFEU as well as the Free Movement Directive and the Asylum Qualifications Directive. Yet, just as in the aforementioned infringement procedures, it also saw a violation of the CFR, as the "Stop Soros" legislation introduced new non-admissibility grounds for asylum applications not regulated by EU law, thus restricting the right to asylum guaranteed in Article 18 (European Commission 2018).

In only two cases did the Commission frame rule of law related concerns solely as breaches of concrete Treaty obligations and secondary law. In the case of the Hungarian National Bank (case 2), an infringement procedure was launched because the new Hungarian Constitution in connection with Act CCVIII of 2011 on the Hungarian National Bank had introduced several provisions threatening its independence. 
The Commission justified the infringement action by referring to Article 130 TFEU on the full independence of the national central banks and to Article 127(4) requiring consultation with the ECB "on any draft legislative provision in its field of competence" (European Commission $2012 \mathrm{a}$ ). In the case of the lowering of the judges', prosecutors' and public notaries' retirement age (case 3 ), which caused the premature retirement of several hundred judges, enabling the government to fill vacant positions with new and loyal candidates (Scheppele 2016, p. 109), the Commission framed the obviously politically motivated replacement of judges exclusively as a breach of Directive 2000/78/EC on equal treatment in employment, which prohibits age discrimination in the workplace (European Commission 2012a). In this case, rule of law related concerns were treated as a matter of age discrimination.

Overall, this demonstrates that even though the Commission did not justify the rule of law-related infringement procedures with violations of the rule of law or democracy as such, and even though it never directly mentioned Article 2 TEU, it also did not simply miscategorise the underlying problems by presenting them as being only breaches of technical legislation. Instead, in most of the cases, it stressed various rights and freedoms constitutive of a democracy, such as the freedom of expression and information (case 1 ), the freedom of assembly and association (case 6), the right to protection of personal data (cases 4 and 6) and academic freedom as well as the right to education (case 5). Obviously, the Commission made a clear effort to link its rule of law concerns to fundamental democratic prerequisites.

\section{From Limited Cooperation to Resistance: The Hungarian Government's Reactions to Rule of LaW-Related Infringement Procedures}

The Hungarian government's reactions to rule of law-related infringement procedures underwent a fundamental change, both in substance and rhetoric. In the beginning, the government presented the infringement procedures as regular, policy-related procedures addressing ordinary transposition problems. It stressed that the Commission never directly referred to fundamental values or rule of law problems (Hungarian Government 2011) and reasoned that there was no conflict concerning 
fundamental values such as the freedom of the press or the independence of the judiciary (Hungarian Government 2012a, b). Disagreements between Brussels and Budapest were explained in terms of differing perspectives on compliance problems, e.g. that the former saw the retirement age of judges as a judicial matter while the latter viewed it as a matter of pensions policy (Hungarian Government 2012d; Orbán 2012). The government underlined that apart from these slightly differing interpretations and smaller technical problems, the Hungarian legislation was overall compatible with EU law and that it just had to be properly explained to the Commission. In this vein, it framed the infringement procedures as a chance for dialogue and an opportunity to resolve conflicts (Hungarian Government 2012a, b). It also displayed its optimism regarding the Commission's “objective, impartial evaluation, which excludes double standards and is founded on a judicial and professional basis" 2 (Hungarian Government 2012c). Last but not least, it stressed Hungary's willingness to comply with the Commission's requirements and CJEU rulings (Hungarian Government 2012a, c).

In accordance with these conciliatory public statements, the Hungarian government changed some parts of the new media legislation package after bilateral talks and enacted these changes through Act XIX of 2011. It also complied with the Commission requirements in case 3 , but only after a ruling by the CJEU had confirmed the Commission's position (EU:C:2012:687). In reaction to the Commission's criticism, Act XX of 2013 re-increased the judges', notaries' and public prosecutors' retirement age gradually to 65 within ten years and also made provisions for reinstating unlawfully dismissed judges unless the position had not been filled yet. In these cases, the former judges should be entitled to financial compensation. Measured solely against the Commission's concrete requirements, these two infringement procedures induced complete compliance.

In contrast, the government's reaction in the cases of the National Bank and of the independence of the data protection authority were mixed, yielding only partial compliance with the Commission's requirements. The Hungarian government deleted some provisions that would have curtailed the National Bank's independence but did not withdraw the criticised changes in the governor's remuneration scheme. Despite

${ }^{2}$ All quotes are own translations. 
this obvious partial compliance, the infringement procedure was closed in April 2012 even before the legislative changes were enacted (European Commission 2012b). The government's legal reaction to the infringement procedure on the independence of the data protection authority provides another example of partial compliance. The government changed the dismissal rules, but left the issue of the data protection ombudsman unresolved. Even though the Commission's position had been confirmed by the CJEU in April 2014 (EU:C:2014:237), the former ombudsman András Jóri was not reinstated, but only given financial compensation. Nevertheless, the Commission silently closed the case in October 2014.

In all four cases mentioned above, however, the underlying rule of law problems have not been resolved. Despite the changes to the media legislation, the government's direct influence on the public broadcasting service has been maintained, as the Media Council's composition remained unchanged. As a result of this direct political influence, independent or left-leaning media were put under severe financial pressure, while a new government-friendly media staffed with public money was established (Várnagy 2017, p. 127). The National Bank's independence has also been severely jeopardised. By appointing the minister of economics György Matolcsy as new governor in 2013, the government managed to install a Fidesz-loyalist as head of the bank (Buckley and Kester 2013), thus ensuring government control despite the legislative changes made in response to the infringement procedure. The same year, the fifth amendment to the constitution merged the Central Bank with the Financial Supervisory Authority, increasing the government's influence on financial and monetary matters. Concerning the independence of the judiciary, the altered legislation remained rather ineffective in practice as the majority of positions had already been filled by then. Many judges, especially in high-ranking positions, therefore, could not return to their former positions. While formally complying with the Commission's requirements, the Hungarian government could still at least partly realise its objective of filling positions with new judges (Scheppele 2016, p. 109f.).

The communication on cases 5, 6 and 7 , in contrast, was highly confrontational, with the government showing hardly any inclination of cooperation or willingness to comply with the Commission's demands. Increasingly, it presented the rule of law-related infringement procedures as political attacks on Hungary due to its resistance against migrants and the EU's migration policy (Orbán 2017a, b). Especially in cases 5 and 6 , the government linked the two rule of law-related infringement 
procedures with two asylum related infringement procedures launched in parallel (see the contribution of Beger in this volume). Reacting to the infringement procedure on the "Stop Soros" package, the government's spokesman put forth that "those who protect Europe are punished while those who send for migrants are praised" (Hungarian Government 2018). Besides, from case 5 onwards, the alleged prominent role of Soros in orchestrating migration across Europe, the "Soros plan", became the government's dominant narrative. As the Prime Minister explained in summer 2017, "bureaucrats of Brussels want to take revenge on Hungary" as the country "is doing its job, is protecting its borders, is defending its citizens" (Orbán 2017a). He added that the bureaucrats "play by Soros's music. There is a Soros plan" (Orbán 2017b). Now, Soros's name figured in almost all public statements on the rule of lawrelated infringement procedures. EU institutions were repeatedly depicted as being infiltrated by "Soros's people" and, therefore, as acting according to his plan. As the Secretary of State for Justice argued, "according to leaked data, George Soros has more than 200 reliable people in the European Parliament alone" (Völner 2017a; also Völner 2017b). Orbán argued similarly that "Brussels is under his influence" and that the "Brussels machinery is executing his plan" (Orbán 2017c). In short, all rule of law-related infringement procedures after 2015 were officially depicted as Soros's "revenge" executed by EU institutions: "We see that the issue of the university, the issue of the 'fake civil society organisations' [...] as well as the issue of quotas lead us to one person called George Soros" (Orbán $2017 \mathrm{~d}$ ). The government has not changed this line of reasoning since; rule of law related criticism by EU actors is regularly depicted as an act to punish Hungary for its migration policy (Hungarian Government 2019; Varga 2019).

In line with its public rhetoric, the Hungarian government refused to change the objectionable legislation even slightly and let the Commission refer them to the CJEU. Regarding the Lex CEU, it insisted that there was no necessity to change the law (Hungarian Government 2017). The complaint against the "Lex CEU" was therefore lodged before the CJEU in December 2017. Similarly, in the case of the NGO law, the Hungarian government did not implement any changes after the Commission's letter of formal notice and its reasoned opinion. Orbán called the Commission's criticism "ridiculous" and far-fetched, saying that an "intelligent lawyer" would not even touch the Commission's document (Orbán 2017c). Therefore, this case was also referred to the CJEU in December 2017 
(European Commission 2017d), being without a ruling thus far. In the so-called Stop Soros case, the Hungarian government not only insisted on its position, rejecting legislative changes even if the case was referred to the CJEU (Hungarian Government 2017; Völner 2017b), the Prime Minister also proclaimed that the Hungarian government was not paying much attention to the matter, as due to the upcoming EP elections, the Commission's days were numbered (Orbán 2018). As a consequence, the Commission referred the case to the Court in July 2019, where it awaits its ruling.

\section{Escalation ANd LeARning EfFects: The InTERPlay Between Brussels and Budapest Since 2010}

As demonstrated above, the limited cooperative stance of the Hungarian government between 2010 and 2013 has turned into grim resistance. While the first four rule of law-related infringement procedures were at least partly successful in legal terms, the last three procedures met fierce opposition. Starting with case 5 in 2017, the Hungarian government has decidedly refused to even slightly change the provisions violating EU law, causing the referral of all cases to the CJEU. ${ }^{3}$

It seems that during this ongoing escalation of conflicts, the Hungarian government's increasingly confrontational stance in the rule of law related cases led the Commission to reconsider its conventional approach of conflict avoidance. In line with previous studies, cases 2 and 4 demonstrate that the Commission first avoided going through all the stages of the infringement procedure. Despite the obvious partial compliance, it closed both cases and did not bring them before the court. However, this hesitant position yielded adverse effects. First, it gave the Hungarian government the chance to downplay the rule of law problems. As the cases were officially closed, it could argue that it had "a confirmation of our freedom of the press being okay, our media regulations being

\footnotetext{
${ }^{3}$ Hungary's overall compliance record has not deteriorated and referrals to the court remain an exception as a closer look at all infringement procedures launched against Hungary since 2010 reveals European Commission (2020). This corroborates earlier findings. Scholars have repeatedly pointed out that the new member states comply even better with EU law than the older member states (Börzel and Sedelmeier 2017). While the EU's influence on "hot topics" decreases, the member states' compliance performance in less controversial areas remains strong (Grabbe 2014, p. 42; see also Schimmelfennig and Sedelmeier 2019).
} 
okay, our electoral law being okay, our constitution being okay" (Orbán $2017 \mathrm{~d}$ ). Similarly, and despite the ongoing deterioration of the media situation which resulted in the "effective take-over of once-independent media" (Joint International Press Freedom Mission 2019), the Secretary of State for International Communication and Relations Zoltán Kovács recently claimed, "if there's a country that holds a certificate showing that its media regulatory system conforms to EU law, it's Hungary" (Kovács 2019).

Secondly, it became obvious that governments can use the long time span between the lodging of a complaint and the court ruling to buy time and meanwhile continue to dismantle democracy and the rule of law. The Lex CEU is just one case in point. When the Hungarian Parliament adopted the law, the Commission acted swiftly and more decisively than before, sending a letter of formal notice to Budapest in April, just a few days after the adoption, followed by a reasoned opinion in July and a referral to the Court in December that year (European Commission $2017 \mathrm{a}, \mathrm{b}, \mathrm{d})$. Since then, the court ruling is pending, while the government has achieved its goal of driving the university out of the country. Although the CEU fulfilled the new requirements for foreign universities, the government did not sign the document that would have allowed the university to run a campus in Budapest. In response, the university partly moved to Vienna (Bárd 2018).

Obviously responding to these adverse effects of recent rule of lawrelated infringement procedures (and without doubt also inspired by the Polish experience), the Commission has announced its intention to deploy the instrument in a more decisive manner and to pursue a "strategic approach". According to the Commission, this strategic approach includes the request for expedited proceedings and interim measures "whenever necessary" (European Commission 2019a). This resonates with scholarly opinions according to which the Commission should "explore the untapped potential of increasing and interconnected infringement actions" (see also Bárd and Śledzińska-Simon 2019; Pech and Kochenov 2019, p. 5).

In addition, the Commission declared that it will "further build on the recent case law of the Court" (European Commission 2019b). In fact, case law is an important source to further determine the meaning of the EU's foundational values and thus to make it a legal basis for rule of law-related infringement procedures. For example, with Case C-64/16, the CJEU developed clear yardsticks to assess the independence of the 
judiciary in EU member states. This might further reduce the risk of miscategorising rule of law problems.

\section{Conclusion}

To contribute to the burgeoning body of research on the EU's tools against rule of law backsliding, this chapter has set out to systematically analyse all rule of law-related infringement procedures launched against Hungary since 2010. Our analysis reveals that even though the Commission did not once directly refer to democracy and the rule of law as enshrined in Article 2 TEU, it did not simply miscategorise the rule of law problems as ordinary instances of non-compliance either. In most of the cases, it referred to fundamental democratic prerequisites, namely rights and freedoms incorporated in the Charter of Fundamental Rights of the European Union.

Secondly, in all cases under investigation, the Hungarian government downplayed the Commission's rule of law concerns. In early cases, it repeatedly talked down the severity of the Commission's complaints by presenting conflicts with Brussels as differences of opinion on technical problems. In later cases, it did so by playing a blame game and adopting a victim narrative, according to which the EU was infiltrated by "Soros people" and going against Hungary because it wanted to punish the country for its restrictive asylum policy. This demonstrates that despite their legal character and formalised procedures, infringement procedures could not contribute to depoliticising the conflicts and thereby ease the strained relations between Budapest and Brussels. On the contrary, as things currently stand, the rule of law-related infringement procedures obviously bear the risk of politicising the judiciary by bringing highly controversial conflicts before the CJEU. It remains to be seen how Hungary will react to the CJEU judgements on the Lex CEU, the NGO law and the "Stop Soros" package.

Thirdly, especially the Hungarian government's open resistance in the last three cases casts doubt on the premise that the correct identification of rule of law and democracy problems could induce compliance with the Commission's requirements. These cases clearly demonstrate that the most important prerequisite for the procedures' effectiveness is the targeted government's willingness to comply. If this is lacking, the categorisation of cases - references to fundamental rights such as freedom of association, academic freedom and the right to asylum-cannot make a 
difference. Nevertheless, the Commission seems determined to draw on recent case law and to establish a clearer link to the rule of law in future cases. ${ }^{4}$

Last but not least, our findings cast doubt on the suitability of another prominent suggestion, namely the creation of a new neutral institution or a "committee of independent experts" (Weber and Di Fabio 2019) as a "democracy watchdog" (Müller 2015, p. 143). If the Commission, the guardian of the treaties, is systematically presented as an agent of Soros, and if its infringement procedures are systematically framed by the Hungarian government as political attacks, there is no reason to expect that the same fate would not befall a new institution of neutral experts. ${ }^{5}$ The same seems true for systemic infringement procedures. While they enable the Commission to approach rule of law problems more systematically, they seem to be even more prone to politicisation and blame games by governments. By starting systemic infringement procedures, the Commission would focus exclusively on the rule of law as well as democracy issues, and the targeted government could easily present these as systematically orchestrated political attacks.

Overall, our analysis shows that the infringement procedures as a legal instrument against rule of law backsliding are not only futile but even counterproductive. It furthermore casts doubt on the premise that a proper application of the instrument will make a difference and yield the desired effects.

\section{Appendix}

\footnotetext{
${ }^{4}$ For a critical discussion of this, see Chapter 14.

${ }^{5}$ For the potential of supporting NGOs as watchdogs of democracy and EU membership, see Chapter 11 .
} 


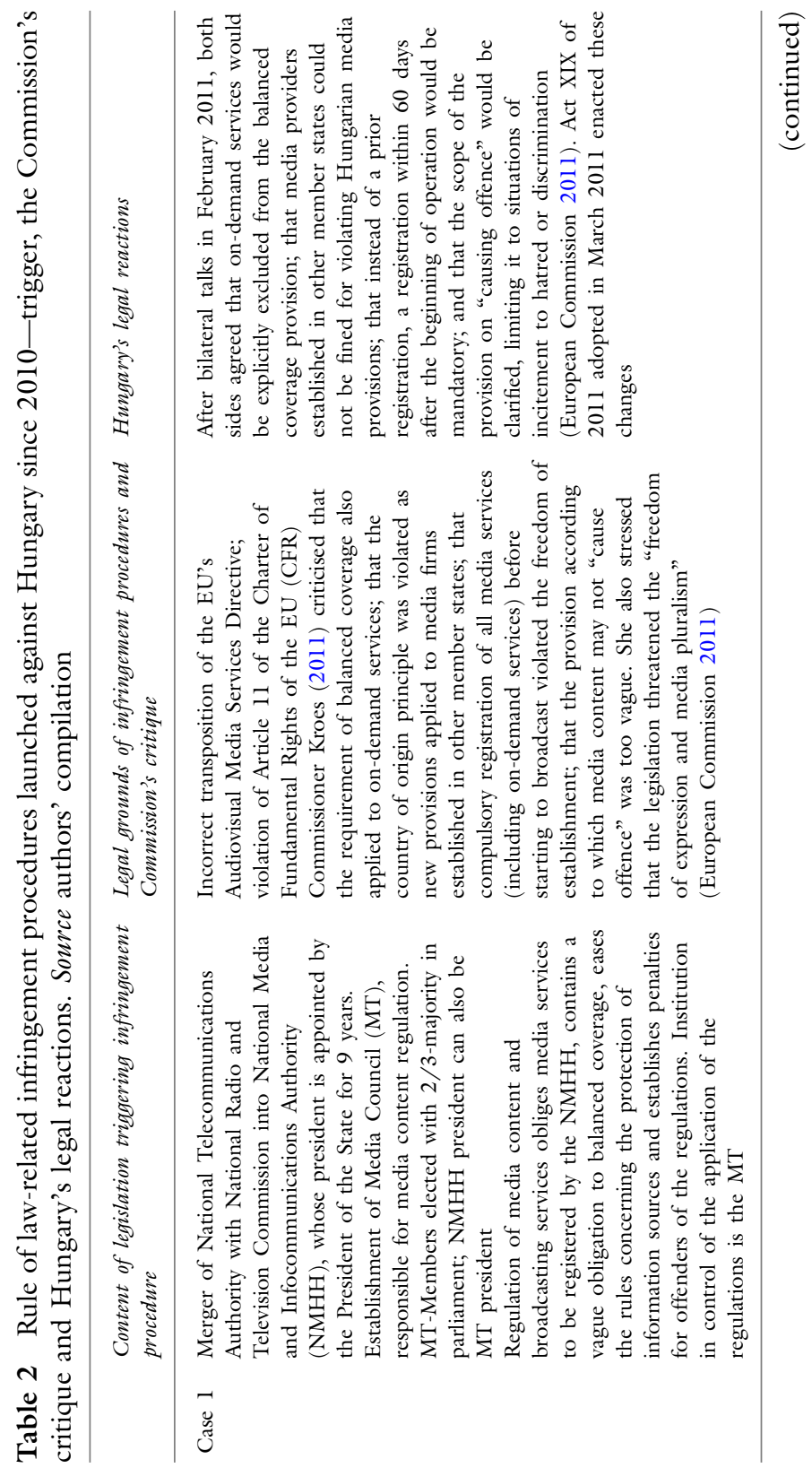




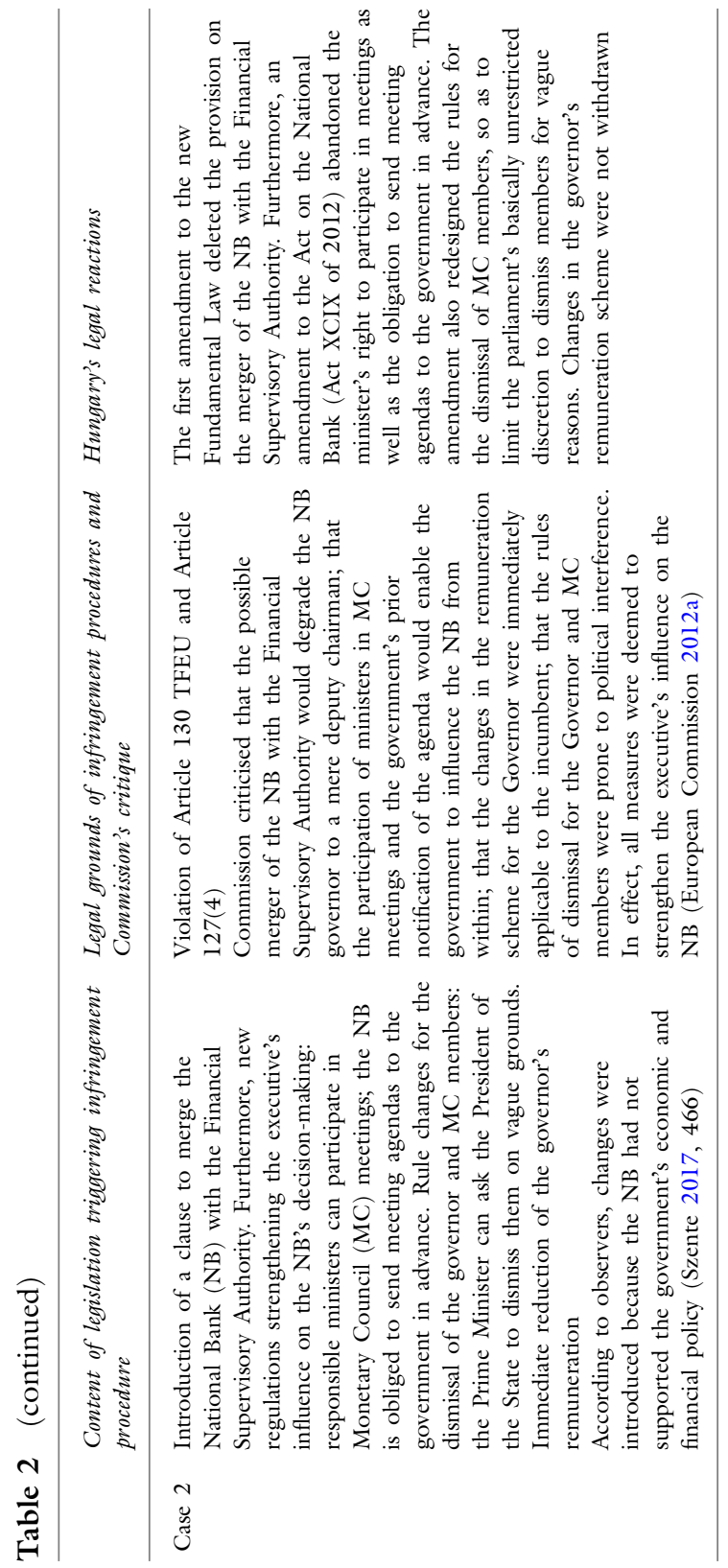




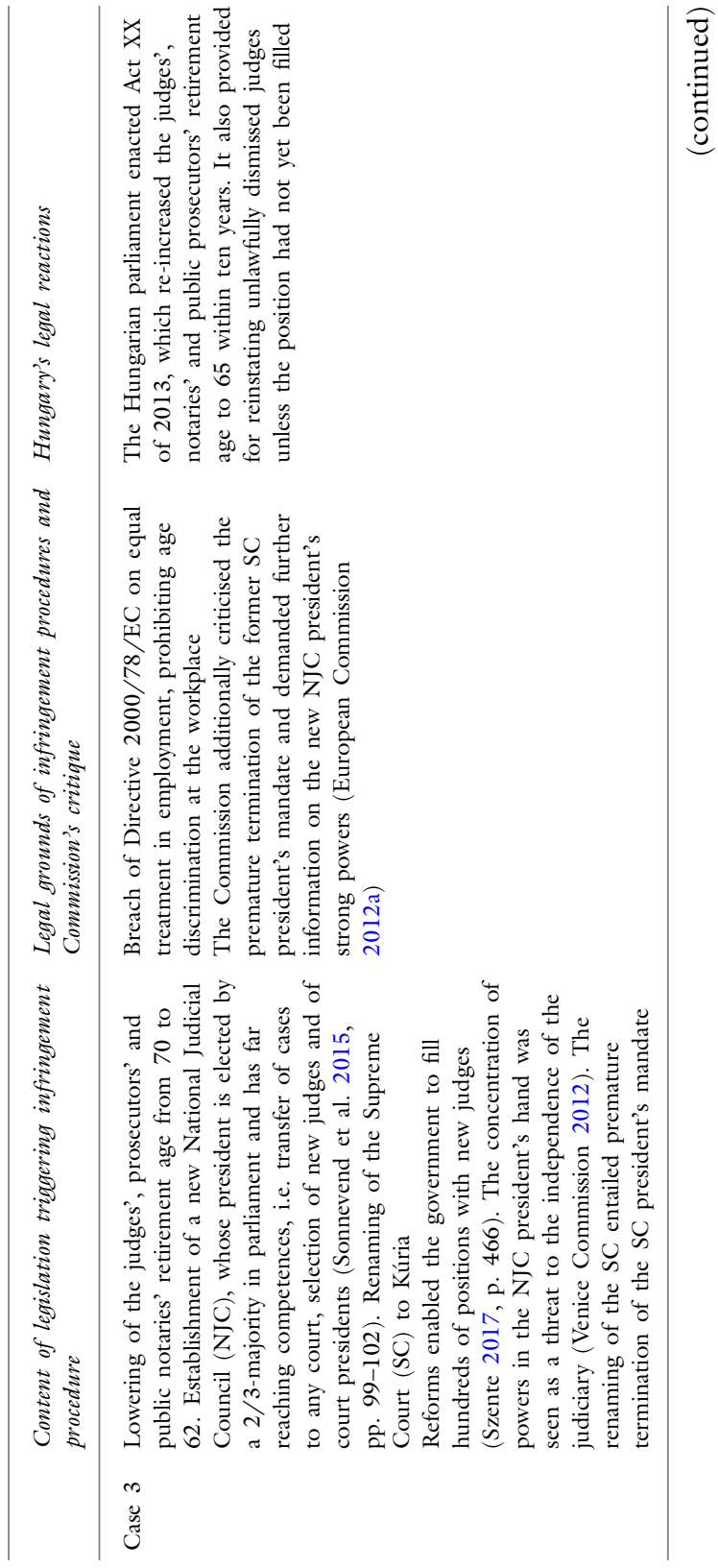




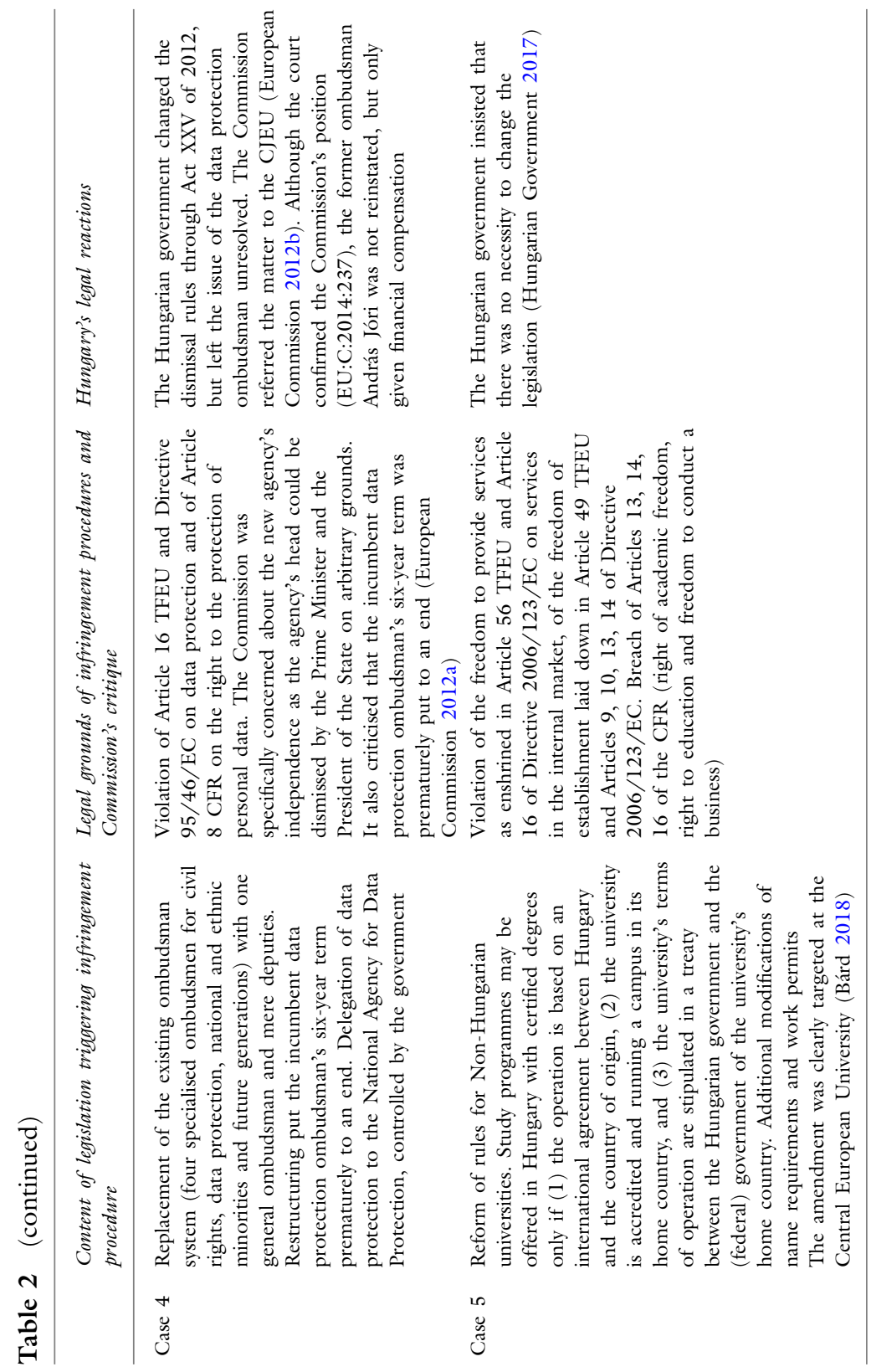




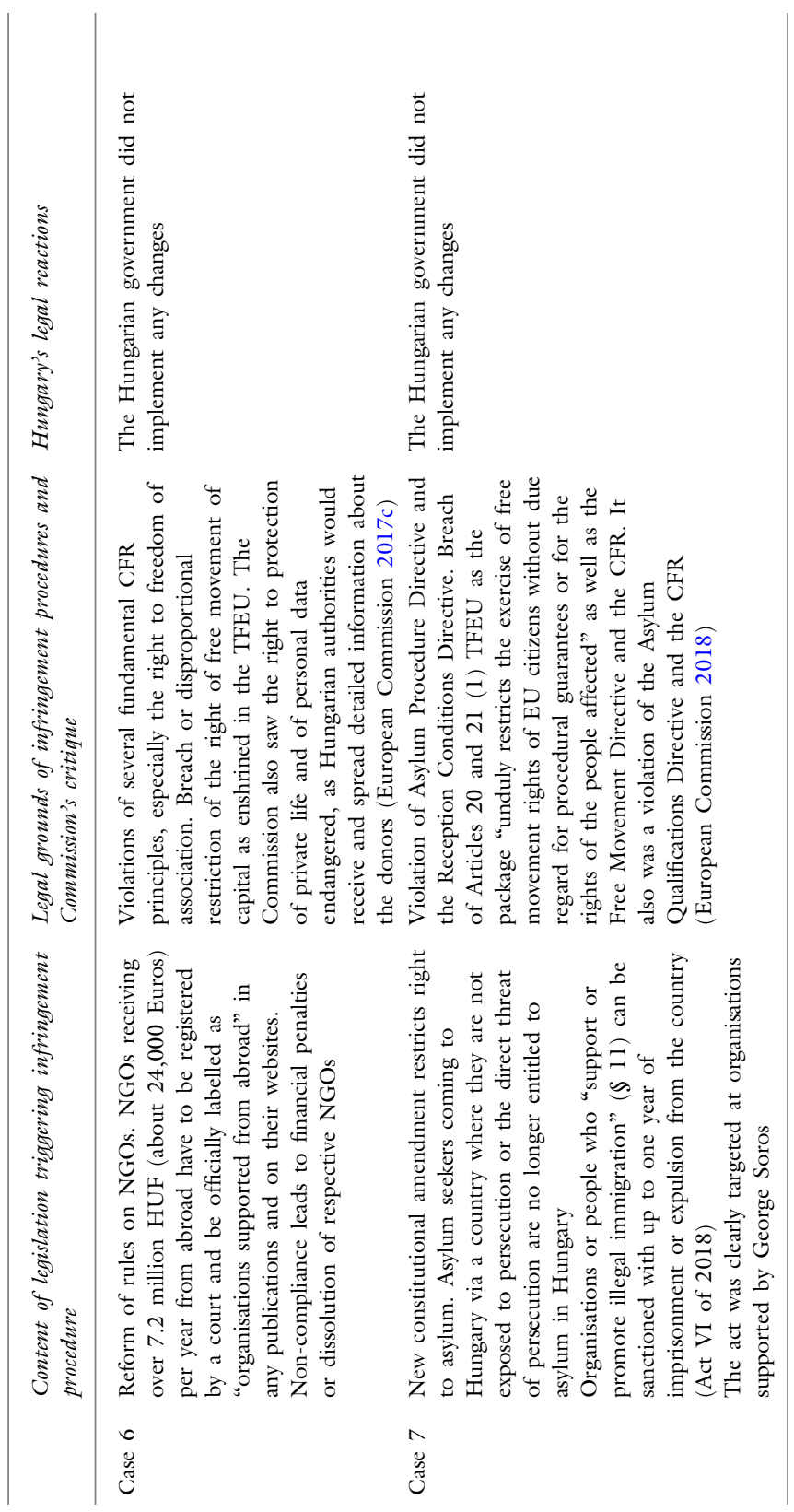




\section{REFERENCES}

Ágh, Attila. 2018. Decline of Democracy in the ECE and the Core-Periphery Divide: Rule of Law Conflicts of Poland and Hungary with the EU. Journal of Comparative Politics 11 (2): 30-48.

Bánkuti, M., G. Halmai, and K. L. Scheppele. 2012. From Separation of Powers to a Government without Checks: Hungary's Old and New Constitutions. In Constitution for a Disunited Nation: On Hungary's 2011 Fundamental Law, ed. Gabor Attila Tóth, pp. 237-268. Budapest: Central European University Press.

Bárd, Petra. 2018. The Rule of Law and Academic Freedom or the Lack of it in Hungary. European Political Science 19: 1-10.

Bárd, P., and A. Sledzińska-Simon. 2019. Rule of Law Infringement Procedures: A Proposal to Extend the EU's Rule of Law Toolbox. CEPS Paper in Liberty and Security 09-2019.

Batory, Agnes. 2016. Defying the Commission: Creative Compliance and Respect for the Rule of Law in the EU. Public Administration 94 (3): 685-699.

Blauberger, M., and R.D. Kelemen. 2016. Can Courts Rescue National Democracy? Judicial Safeguards Against Democratic Backsliding in the EU. Journal of European Public Policy 24 (3): 321-336.

Börzel, Tanja Anita. 2003. Guarding the Treaty: The Compliance Strategies of the European Commission. In The State of the European Union: Vol. 6. Law, Politics, and Society, ed. T.A. Börzel and R.A. Cichowski, 197-220. Oxford: Oxford University Press.

Börzel, T.A., and U. Sedelmeier. 2017. Larger and More Law Abiding? The Impact of Enlargement on Compliance in the European Union. Journal of European Public Policy 24 (2): 197-215.

Buckley, N., and E. Kester. 2013. Matolcsy Named Hungary Central Bank Chief. Financial Times, March 1. Retrieved from https://www.ft.com/content/f65 d7754-8256-11e2-8404-00144feabdc0. Accessed 24 March 2020.

Closa, Carlos. 2019. The Politics of Guarding the Treaties: Commission Scrutiny of Rule of Law Compliance. Journal of European Public Policy 26 (5): 696716.

Dawson, M., and E. Muir. 2012. Enforcing Fundamental Values: EU Law and Governance in Hungary and Romania. Maastricht Journal of European and Comparative Law 19 (4): 469-476.

European Commission. 2011. Media: Commission Vice-President Kroes Welcomes Amendments to Hungarian Media Law, February 16. MEMO/11/89 [Press release]. Brussels. Retrieved from https://ec.europa.eu/commission/pressc orner/detail/en/MEMO_11_89. Accessed 24 March 2020.

European Commission. 2012a. European Commission Launches Accelerated Infringement Proceedings Against Hungary over the Independence of Its Central Bank and Data Protection Authorities as Well as over Measures 
Affecting the Judiciary, January 17 [Press release]. Retrieved from https:// ec.europa.eu/commission/presscorner/detail/en/IP_12_24. Accessed 24 March 2020.

European Commission. 2012b. Hungary-Infringements: European Commission Satisfied with Changes to Central Bank Statute, But Refers Hungary to the Court of Justice on the Independence of the Data Protection Authority and Measures Affecting the Judiciary, April 25 [Press release]. Retrieved from http://europa.eu/rapid/press-release_IP-12-395_en.htm. Accessed 24 March 2020.

European Commission. 2014. Communication from the Commission to the European Parliament and the Council: A New EU Framework to Strengthening the Rule of Law, March 11 (COM(2014) 158 final). Brussels.

European Commission. 2017a. Hungary: Commission Takes Legal Action on Higher Education Law and Sets Record Straight on 'Stop Brussels' Consultation, April 26 [Press release]. Brussels. Retrieved from https://ec.europa.eu/com mission/presscorner/detail/en/MEX_17_1116. Accessed 24 March 2020.

European Commission. 2017b. Hungary: Commission Takes Second Step in Infringement Procedure on Higher Education Law, July 13 [Press release]. Brussels. Retrieved from http://europa.eu/rapid/press-release_IP17-1952_en.htm. Accessed 24 March 2020.

European Commission. 2017c. Infringements-Hungary: Commission Launches Infringement Procedure for Law on Foreign-Funded NGOs, July 13 [Press release]. Brussels. Retrieved from http://europa.eu/rapid/press-release_IP17-1982_en.htm. Accessed 24 March 2020.

European Commission. 2017d. Infringements-European Commission Refers Hungary to the Court of Justice for Its NGO Law, December 7 [Press release]. Brussels. Retrieved from http://europa.eu/rapid/press-release_IP17-5003_en.htm. Accessed 24 March 2020.

European Commission. 2018. Migration and Asylum: Commission Takes Further Steps in Infringement Procedures Against Hungary, July 19 [Press release]. Retrieved from http://europa.eu/rapid/press-release_IP-18-4522_en.htm. Accessed 24 March 2020.

European Commission. 2019a. COM (2019) 343 final. Communication from the Commission to the European Parliament, the European Council and the Council, the European Economic and Social Committee and the Committee of the Regions: Strengthening the Rule of Law within the Union, July 17.

European Commission. 2019b. COM(2019) 163 final. Communication from the Commission to the European Parliament, the European Council and the Council: Further Strengthening the Rule of Law within the Union, April 3.

European Commission. 2020. European Commission at Work Database. Retrieved from https://ec.europa.eu/atwork/applying-eu-law/infringem 
ents-proceedings/infringement_decisions/?lang_code=en. Accessed 24 March 2020.

Grabbe, Heather. 2014. Six Lessons of Enlargement Ten Years on: The EU's Transformative Power in Retrospect and Prospect. JCMS: Journal of Common Market Studies 52 (sl): 40-56.

Hillion, Christophe. 2016. Overseeing the Rule of Law in the EU. In Reinforcing Rule of Law Oversight in the European Union, ed. C. Closa and D. Kochenov, 59-81. Cambridge: Cambridge University Press.

Hungarian Government. 2011. A kormány egy hét múlva válaszol a Bizottság észrevételeire. Retrieved from http://2010-2014.kormany.hu/hu/kozigazga tasi-es-igazsagugyi-miniszterium/tarsadalmi-kapcsolatokert-felelos-allamtitk arsag/hirek/a-kormany-egy\%E2\%80\%A6. Accessed 24 March 2020.

Hungarian Government. 2012a. Az Európai Bizottság 2012. január 17-ei döntése a Magyarországgal szemben inditandó kötelezettségszegési eljárásokról. Retrieved from http://2010-2014.kormany.hu/hu/miniszterelnokseg/ hirek/harom-kotelezettsegszegesi-eljarast-indit-hazank-ellen-az-europai-biz ottsag. Accessed 24 March 2020.

Hungarian Government. 2012b. Kovács Zoltán: a magyar médiaszabályozás igazodik a hazai körülményekhez. Retrieved from https://2010-2014.kor many.hu/hu/kozigazgatasi-es-igazsagugyi-miniszterium/tarsadalmi-kapcsolat okert-felelos-allamtitkarsag/hirek/kovacs-zoltan-a-magyar-mediaszabalyozasigazodik-a-hazai-korulmenyekhez. Accessed 30 March 2020.

Hungarian Government. 2012c. A kormány elküldte válaszleveleit az Európai Bizottságnak. Retrieved from http://2010-2014.kormany.hu/hu/miniszter elnokseg/hirek/a-kormany-elkuldte-valaszleveleit-az-europai-bizottsagnak.

Accessed 24 March 2020.

Hungarian Government. 2012d. Szijjártó Péter: lesznek azonnali módositások. Retrieved from http://2010-2014.kormany.hu/hu/miniszterelnokseg/ hirek/szijjarto-peter-lesznek-azonnali-modositasok. Accessed 24 March 2020.

Hungarian Government. 2017. A kötelezó kvóta megbukott. Retrieved from http://www.kormany.hu/hu/miniszterelnokseg/hirek/a-kotelezo-kvotamegbukott. Accessed 24 March 2020.

Hungarian Government. 2018. Aki védi Európát, azt eljárás alá vonják, aki bebívja a migránsokat, azt megdicsérik. Retrieved from http://www.kormany. $\mathrm{hu} / \mathrm{hu} /$ miniszterelnokseg/hirek/aki-vedi-europat-azt-eljaras-ala-vonjak-akibehivja-a-migransokat-azt-megdicserik. Accessed 24 March 2020.

Hungarian Government. 2019. Chorus of Soros Organisations Lined Up This Morning. Retrieved from https://www.kormany.hu/en/government-spokes person/news/chorus-of-soros-organisations-lined-up-this-morning. Accessed 24 March 2020.

Jenne, E.K., and C. Mudde. 2012. Hungary's Illiberal Turn: Can Outsiders Help? Journal of Democracy 23 (3): 147-155. 
Joint International Press Freedom Mission. 2019. Conclusions of the Joint International Press Freedom Mission to Hungary. Retrieved from https://ipi. media/wp-content/uploads/2019/12/Hungary-Conclusions-InternationalMission-Final.pdf. Accessed 24 March 2020.

Kovács, Zoltán. 2019. Even Slovenia Is Worried.... Retrieved from https:// twitter.com/zoltanspox/status/1204356847915995138. Accessed 24 March 2020.

Kroes, Neelie. 2011. Hungary's New Media Law: Open Hearing on Freedom of the Press in Hungary, January 11. European Parliament, Brussels. Retrieved from https://europa.eu/rapid/press-release_SPEECH-11-6_en.pdf. Accessed 24 March 2020.

Magen, Amichai. 2016. Cracks in the Foundations: Understanding the Great Rule of Law Debate in the EU. Journal of Common Market Studies 54 (5): 1050-1061.

Merkel, Wolfgang. 2012. Measuring the Quality of Rule of Law. In Rule of Law Dynamics: In an Era of International and Transnational Governance, ed. M. Zürn, A. Nollkaemper, and R.P. Peerenbom, 21-47. Cambridge: Cambridge University Press.

Müller, Jan-Werner. 2015. Should the EU Protect Democracy and the Rule of Law Inside Member States? European Law Journal 21 (2): 141-160.

Orbán, Viktor. 2012. GDP-adat: az irányt eltaláltuk. Retrieved from http://2010-2015.miniszterelnok.hu/interju/gdp-adat_az_iranyt_eltala ltuk. Accessed 24 March 2020.

Orbán, Viktor. 2017a. Orbán Viktor a Kossuth Rádió „180 perc” cimü müsorában. Retrieved from http://www.kormany.hu/hu/a-miniszterelnok/beszedek-pub likaciok-interjuk/orban-viktor-a-kossuth-radio-180-perc-cimu-musoraban20170428. Accessed 24 March 2020.

Orbán, Viktor. 2017b. Orbán Viktor a Kossuth Rádió „180 perc” cimü müsorában. Retrieved from http://www.kormany.hu/hu/a-miniszterelnok/ beszedek-publikaciok-interjuk/orban-viktor-a-kossuth-radio-180-perc-cimumusoraban-20170721. Accessed 24 March 2020.

Orbán, Viktor. 2017c. Orbán Viktor a Kossuth Rádió „180 perc” cimü müsorában. Retrieved from http://www.kormany.hu/hu/a-miniszterelnok/beszedek-pub likaciok-interjuk/orban-viktor-a-kossuth-radio-180-perc-cimu-musoraban20171006. Accessed 24 March 2020.

Orbán, Viktor. 2017d. Orbán Viktor interjúja az Echo TV „Napi aktuális” címü müsorában. Retrieved from http://www.kormany.hu/hu/a-miniszterelnok/ beszedek-publikaciok-interjuk/orban-viktor-interjuja-az-echo-tv-napi-aktualiscimu-musoraban. Accessed 24 March 2020.

Orbán, Viktor. 2018. Orbán Viktor a Kossuth Rádió „180 perc” cimü müsorában. Retrieved from http://www.kormany.hu/hu/a-miniszterelnok/beszedek-pub 
likaciok-interjuk/orban-viktor-a-kossuth-radio-180-perc-cimu-musoraban201 80727. Accessed 24 March 2020.

Panke, Diana. 2010. The Effectiveness of the European Court of Justice: Why Reluctant States Comply. Manchester: Manchester University Press.

Pech, L., and D. Kochenov. 2019. Strengthening the Rule of Law within the European Union: Diagnoses, Recommendations, and What to Avoid. Policy Brief-June 2019. Retrieved from https://reconnect-europe.eu/wp-con tent/uploads/2019/06/RECONNECT-policy-brief-Pech-Kochenov-201

9June-publish.pdf. Accessed 24 March 2020.

Pech, L., and K.L. Scheppele. 2017. Illiberalism within: Rule of Law Backsliding in the EU. Cambridge Yearbook of European Legal Studies 19: 3-47.

Polyák, Gábor. 2015. Context, Rules and Praxis of the New Hungarian Media Laws: How Does the Media Law Affect the Structure and Functioning of Publicity. In Constitutional Crisis in the European Constitutional Area: Theory, Law and Politics in Hungary and Romania, ed. A.V. Bogdandy and P. Sonnevend, 125-150. Baden-Baden: Nomos.

Priebus, Sonja. 2016. Hungary. In Constitutional Politics in Central and Eastern Europe, ed. A. Fruhstorfer and M. Hein, 101-143. Wiesbaden: Springer.

Reding, Viviane. 2013. The EU and the Rule of Law-What Next? September 4. Brussels. Retrieved from http://europa.eu/rapid/press-release_SPEECH13-677_de.htm. Accessed 24 March 2020.

Scheppele, Kim Lane. 2016. Enforcing the Basic Principles of EU Law Through Systemic Infringement Actions. In Reinforcing Rule of Law Oversight in the European Union, ed. C. Closa and D. Kochenov, 105-132. Cambridge: Cambridge University Press.

Schimmelfennig, F., and U. Sedelmeier. 2019. The Europeanization of Eastern Europe: The External Incentives Model Revisited. Journal of European Public Policy 19 (2): 1-20.

Schlipphak, B., and O. Treib. 2016. Playing the Blame Game on Brussels: The Domestic Political Effects of EU Interventions Against Democratic Backsliding. Journal of European Public Policy 24 (3): 352-365.

Schmidt, M., and P. Bogdanowicz. 2018. The Infringement Procedure in the Rule of Law Crisis: How to Make Effective Use of Article 258 TFEU. Common Market Law Review 55: 1061-1100.

Sonnevend, Pál, András Jakab, and Lóránt Csink. 2015. The Constitution as an Instrument of Everyday Party Politics: The Basic Law of Hungary. In Constitutional Crisis in the European Constitutional Area: Theory, Law and Politics in Hungary and Romania, ed. A.V. Bogdandy and P. Sonnevend, 33-109. Baden-Baden: Nomos.

Szente, Zoltán. 2017. Challenging the Basic Values: The Problems of the Rule of Law in Hungary and the Failure of the European Union to Tackle Them. In 
The Enforcement of EU Law and Values: Ensuring Member States' Compliance, ed. A. Jakab and D. Kochenov, 456-475. Oxford: Oxford University Press.

Varga, Judit. 2019. Facts You Always Wanted to Know About Rule of Law But Never Dared to Ask. Euronews, November 22. Retrieved from https://www. euronews.com/2019/11/19/judit-varga-facts-you-always-wanted-to-knowabout-rule-of-law-hungary-view. Accessed 24 March 2020.

Várnagy, Réka. 2011. Hungary. European Journal of Political Research 50 (7-8): 991-998.

Várnagy, Réka. 2017. Hungary. European Journal of Political Research Political Data Yearbook 56 (1): 123-128.

Venice Commission. (2012). Opinion on the Cardinal Acts on the Judiciary That Were Amended Following the Adoption of Opinion CDL-AD(2012)001 on Hungary: Adopted by the Venice Commission at Its 92nd Plenary Session. Retrieved from https://www.venice.coe.int/webforms/documents/default. aspx?pdffile=CDL-AD(2012)020-e. Accessed 7 May 2020.

Völner, Pál. 2017a. Kötelezettségszegési eljárást inditott Magyarország ellen az Európai Bizottság a civil törvény miatt. Retrieved from https://www.kor many.hu/hu/igazsagugyi-miniszterium/parlamenti-allamtitkarsag/beszedekpublikaciok-interjuk/kotelezettsegszegesi-eljarast-inditott-magyarorszag-ellenaz-europai-bizottsag-a-civil-torveny-miatt. Accessed 30 March 2020.

Völner, Pál. 2017b. Nem vonjuk vissza a Stop Sorost. Retrieved from http:// www.kormany.hu/hu/igazsagugyi-miniszterium/parlamenti-allamtitkarsag/ beszedek-publikaciok-interjuk/nem-vonjuk-vissza-a-stop-sorost. Accessed 24 March 2020.

Weber, M., and U. Di Fabio. 2019. My Plan for Defending Rule of Law in EU. EUobserver, March 18. Retrieved from https://euobserver.com/opi nion/144429. Accessed 24 March 2020. 
Open Access This chapter is licensed under the terms of the Creative Commons Attribution 4.0 International License (http://creativecommons.org/licenses/ by $/ 4.0 /$ ), which permits use, sharing, adaptation, distribution and reproduction in any medium or format, as long as you give appropriate credit to the original author(s) and the source, provide a link to the Creative Commons license and indicate if changes were made.

The images or other third party material in this chapter are included in the chapter's Creative Commons license, unless indicated otherwise in a credit line to the material. If material is not included in the chapter's Creative Commons license and your intended use is not permitted by statutory regulation or exceeds the permitted use, you will need to obtain permission directly from the copyright holder.

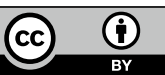

